\title{
VERIFICATION OF THE POSSIBILITY OF USING GEOGRAPHICAL INFORMATION SYSTEMS TO IDENTIFY NEW EDUCATIONAL TRAILS IN THE CZECH BORDER - JESENIKY REGION
}

\author{
ONDREJ PALENČAR
}

Brno University of Technology, Faculty of Architecture, Poříćí 5, 63900 Brno, Czech Republic Tutor: doc. Ing.arch. Gabriel Kopáčik, Dr.

Theme of the dissertation: Revision of approach to rural settlements and its surroundings in the post-agrarian period xapalencar@fa.vutbr.cz

\begin{abstract}
The area of Jeseníky has a rich history, but its continuity was disrupted during the 20th century. Traces of "landscape memory“ can be found in the form of small sacral architecture, historical paths, trees and border stones. This paper verifies the possibility of using GIS to track it, and transform fragments of urbanised countryside into new educational and sports trails. The aim is to provide a better understanding of the fragile relationship between landscape and urban areas in the region and its history.
\end{abstract}

KEY WORDS: GIS, educational trails, landscape memory, Rychlebské trails, restoration of sacral architecture

\section{Introduction}

Interest in spending leisure time in nature is increasing. It is no longer a pastime only for the urban population, but also for villagers, who historically used to spend their free time in the fields. Many studies, such as Cooperation is in our nature: Nature exposure may promote cooperative and environmentally sustainable behavior (ZELENSKI J.M., DOPKO R.L., CAPALDI C.A., 2015), show that there are not only benefits related to our health in spending free time in nature. In 2020, due to the Covid-19 pandemic, it was not possible to travel abroad. Domestic tourism increased, which has a negative effect on our most visited areas. It is already clear today, that tourist areas in the Czech 
Republic should be expanded. The selection of new interesting tourist areas should not be artificial. It is much easier to enlarge already active areas than to create new ones.

To increase the interest in an area, contemporary art and architecture could be used. As Moore describes in his article (MOORE R., 2017), contemporary architecture helped to increase tourism in the quiet, post-industrial city of Bilbao. By this logic, it could be possible to use this "Guggenheim effect" for example through landart or architecture in nature. These tendencies are already visible in the Jeseníky. One of the most photographed objects near the town of Javorník is a sculpture of timber chairs.on Lánský hill.

In my opinion, the restoration of small elements in the countryside has great potential to provide better understanding of the fragile relationship between landscape and urban areas in the region. For example, the importance of the restoration of the Baroque landscape in South Moravia is addressed by the work of Ponešová and Foretník (PONEŠOVÁ B., FORETNÍK J., 2016). The result of their work is not only an analysis of the mentioned landscape, but also a number of proposals for its restoration and activation. Small sacral architecture was often built at intersections or along important paths and footpaths. At the same time, the choice of the site was unrepeatable. From such places, we can often see the urbanised structure of villages, the dominant landmark of a church or significant hill. The passion and crucifixes have the potential to become a guide to the landscape. As Cílek says, it helps us to perceive the surroundings through the eyes of our ancestors and allows us to share a common space even at a different time (CÍLEK V. 2010, p.48) and in a different context.

Another interesting work is a study entitled Landscape of Data - Virtual Reconstruction of the Lost Šumava (GOGOLÁK I., GRASSE L., HORNÍČKOVÁ K., PACLÍKOVÁ K., PREUSZ M., TREJBAL J., ZIFČÁK Š., 2018), published in the magazine Zlatý řez. It deals with the mapping of extinct municipalities in the Vysočina region, their digitisation and conversion into a $3 \mathrm{D}$ model. The model was uploaded to a program that allows you to perceive a non-existent village in augmented reality. The visitor can thus better imagine where the individual houses stood and how they were arranged. This unusual approach helps to create a better understanding of the history of the area and to increase public interest in it.

The ecological aspect of the restoration of historical paths and creation of new trails is also very important. Present-day paths used to cross the vast fields helping people to walk freely through the countryside. Over time, however, the fields were ploughed and combined into large units. Heller states that more than a hundred mayors have now joined the "1000 a 1 cesta pro krajinu" (1000 and 1 roads for the landscape") project, restoring at least a thousand ploughed roads. Besides serving the tourists, they keep the 

expansion of tourism in north Jeseniky by using GIS and analysis of historical maps

water in the landscape thanks to anti-erosion zones or alleys possibly forming along them. (HELLER J., 2019). The restoration of field roads is one of the most important tools of municipalities to support the sustainability of water in the landscape. These roads are captured in old maps and often remain the property of the municipality. (ČÍŽEK P., in HELLER J. 2019) The result should be a permeable, sustainable diversified landscape, self-sufficient in rainwater distribution.

Modern technology could be used to identify suitable trails. Geographical information systems are already used to identify ideal trails for technical networks. It has been proved, that they can also be helpful in searching to expand the network of cycling paths (BÍL M., BÍLOVÁ M., KUBEČEK J, 2012). However, they have never been used in combination with the "points of interest" in the field of art and architecture.

You will get to know the Sudetenland for the first generation of immigrants - either they have nothing to do with the landscape at all, or they won't begin to discover it until they are old. The second and third generations were born here and are already at home. They begin to own the landscape and the landscape begins to own them. Their dead are somehow trying to live with the first settlers. It's tough and it takes time. CÍLEK V. (2010, p.116)

\section{Essence of the project}

The area of the Czech borderlands has been less populated since the Middle Ages due to the demanding, mountainous, and climatic conditions, and frequent military skirmishes. Interest in it only increased during the Industrial Revolution, when industry and mining developed rapidly in some border areas. The cultural and economic expansion of this area was suspended mainly by a series of events after World War II when the native German population was evicted on the basis of Benešs decrees, thus breaking not only the continuity of development, but also cultural and social ties. The new population that settled here had almost no relation to the landscape. The onset of communism and its collectivisation policy left agricultural production, as well as the entire cultural landscape, in a state of disrepair.

Nowadays, the original style of cattle breeding is slowly returning to some areas, and small organic farms are being set up. The area between Javorník, Vidnava, Černá Voda, Lipová-Lázně and the town of Jeseník was chosen as the main area of research.

The transport accessibility of the area is relatively good, the direct connections of the town of Jeseník with Brno and Prague, a good connection to Ostrava, as well as a dense network of regular bus services and a railway line, could be a prerequisite for rapid development. Although this area is located only $23 \mathrm{~km}$ from the popular 
Ramzová ski resort, 20 km from Lázně Jeseník, and 30 km from the Niské Lakes (Poland), visits to these parts were very infrequent in the past.

However, around 2008, near the village of Černá Voda, local enthusiasts began to build a network of downhill trails for mountain bikes. The original idea was to build new routes according to modern trends. Based on an initiative of Lesy ČR (Czech Forests), the owners of part of the land, the restoration of old hunting trails as the main backbone of a network of trails was finally promoted. Thank to this unobtrusive idea, the memory of our ancestors is revived in the atmosphere of the Rychlebské trails.

Nowadays, the Rychlebské trails are considered to be one of the largest and best quality downhill areas in the country. Their attendance has increased sharply in recent years, and nowadays people from Prague, Slovakia, and Poland come here to spend their holidays. A rapid increase in demand for accommodation accompanied this phenomenon. In the village of Černá Voda, many half-dilapidated houses were restored and transformed into boarding houses, small hotels and eco-resorts. Several new pubs, a fisherman's bastion and a bakery were built here. Currently, the tourists interest exceeds the capacity of the village. It might seem that everything is fine, tourism in the area is alive and everything works well. The problem, however, is the narrow centralisation of tourism resulting in an excessive burden on Černá Voda, while the economic situation of its surroundings is not improving much. The houses in the surrounding villages are still neglected, dilapidated or completely ruined. There are only a few job opportunities and it is necessary to commute far. Salaries are well below the average in the Czech Republic. Young people are moving to cities and villages are gradually being depopulated. Simillar tourist attractions, such as narrowly concentrated Rychlebské trails, are missing in the area.

The questionnaire, which was conducted in the summer of 2021 in Černá Voda, showed that the vast majority of visitors to the Rychlebské trails are men aged 2040. Thus, the assumption that this is a specific adrenaline issue for a narrow circle of visitors was confirmed. Probably, the creation of new, less demanding routes full of attractions and natural monuments could increase the interest, for example, of families with children, and older age groups .

\section{Landscape memory}

The landscape in the area is beautiful. Rolling hills, great views, rocks, flooded quarries, endless pastures, herds of cows, and forests. Compared to other popular areas, it has something extra - a painful history that led to the extinction of man-made beauties. It is unbelievable how many church spires and entire depopulated villages 
Possibilities of connecting the restoration of small sacral architecture and the expansion of tourism in north Jeseniky by using GIS and analysis of historical maps

Ondrej Palenčar

have been the target of military exercises. The Church of St. Barbara in the completely destroyed village of Zálesí, and the Chapel of St. Joseph in the village of Hraničky, which has just one house remaining, are two examples. Due to collectivisation, many roads and footpaths disappeared or fell into disrepair, and the small sacral architecture, which sensitively completed the landscape in the past, fell victim to communist ideology or weather conditions. The restoration of the extinct routes, the preservation of dilapidated elements of sacral architecture, as well as reminders of the powerful history of the place could become a key theme of tourism in this area.

\section{Methodology}

To verify if GIS could help with selection of historical monuments that should be restored, and also to identify new trails we will need specific data.

In the first phase, it is necessary to select suitable paths (linear elements). The road

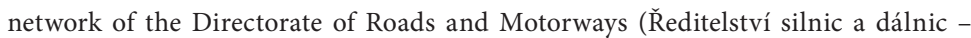
ŘSD) will serve as input data. However, sports and recreational routes will try to avoid these routes. Furthermore, it is necessary to select suitable existing field paths and footpaths based on visual mapping in the field. Analysis of important extinct paths, based on historical mapping from 1836 or old chronicles, is another suitable basis. Topographic analysis will not be important for the purposes of this project. We assume that the main backbone of the network will be field roads, which, as they were originally intended for wagons hauled by cattle, could not be too steep in nature.

In the second phase, it will be necessary to identify potential points of interest (point elements). The GPS coordinates of dilapidated monuments from the zanikleobce.cz and zaniklekostely.cz servers will serve as an important basis. These were created on the initiative of an association of volunteers who map them. Many monuments are still in relatively good condition and their restoration or reconstruction would not be difficult.

The resulting suitable routes are obtained by creating envelope curves, for example, at a distance of $20 \mathrm{~m}$ from the selected paths (line elements), which would contain points of interest (point elements).

\section{Results and discussion}

By this method the selection of suitable trails is very simple. Programs such as QGis and ArcGis offer basic tools to create a quick analysis based on the envelope curves method. Selecting points of interest, that are included on the surface of envelope curves, is also one of the basic tools. 
The main issue is the collection of GPS data. If an Excel table containing all the GPS coordinates of individual objects was available, data would not have to be filled in manually. Analysing historical maps is also not easy, since many of them are incomplete.

It is clear that the analysis could be deeper or more specific. Additional input data, such as infrastructure, land-ownership, terrain profile, the possibility of connection to existing trails, important natural monuments or prospects selected by field research, could change the results and it could help to improve selection. It is also important to design a system to evaluate or simulate the effects of new and old trails on the region.

\section{Conclusion}

The selection of suitable trails is not the end result. It is also important to continue with a design phase. Simple restoration of sacral monuments might not be enough. Due to the rather atheistic period we live in, and the consequent limited presence of religious agricultural workers on the fields, the importance of sacral buildings in the landscape is disappearing. The new generation would be able to form a more modern view of their renewal. For such a task, well known artists could be invited, or a workshop for students of art and architecture could be organised.

Based on the above assumptions, it is clear that GIS could help to identify new trails which could disperse tourism to wider areas and enrich awareness of the area's history.

\section{References}

BÍL M., BÍLOVÁ M., KUBEČEK J., Unified GIS database on cycle tourism infrastructure, Tourism Management, Volume 33, Issue 6, December 2012, Pages 1554-1561

CÍLEK V., Krajiny vnitřní a vnější, texty o paměti krajiny, smysluplném bobrovi, areálu jablkového štrúdlu a také o tom, proč le $\neg z e m e$ na rozhlednu, Dokořán 2010, ISBN 80-7363-042-7

GOGOLÁK I., GRASSE L., HORNÍČKOVÁ K., PACLÍKOVÁ K., PREUSZ M., TREJBAL J., ZIFČÁK Š., Krajina dat - virtuální rekonstrukce ztracené Šumavy, 2018, Zlatý řez 40, ISBN: 1210-4760

HELLER J., Starostové chtějí obnovit tisíce dávno zaoraných cest. Pomůže to krajině i turistům, aktualne.cz, 2019; https://zpravy.aktualne.cz/domaci/starostove-chteji-obnovit-tisice-davno-zaoranych-cest/r 1eea3738a3bc1le9be22a $\neg$ clf6b220ee8/

MOORE R., The Bilbao effect: how Frank Gehry's Guggenheim started a global craze, 2017, The Guardian, https://www.theguardian.com/artanddesign/2017/oct/01/ 
48 Possibilities of connecting the restoration of small sacral architecture and the expansion of tourism in north Jeseniky by using GIS and analysis of historical maps Ondrej Palenčar

bilbao-effect-frank-gehry-guggenheim-global-craze

PONEŠOVÁ B., FORETNÍK J., Krajina jako dílo. Barokní krajinou od Mikulova po Znojmo, 2016, Brno, NPÚ ÚOP v Brně, ISBN: 978-80-87967-08-9

ZELENSKI J.M., DOPKO R.L., CAPALDI C.A., Cooperation is in our nature: Nature expousure may promote cooperative and enviromentally sustainable behavior, Journal of Environmental Psychology, Volume 42, June 2015, Pages 24-31, https:// www.sciencedirect.com/science/article/pii/S0272494415000195 